Alexander Zorin

\title{
A Dunhuang Tibetan Manuscript of "Ārya-samādhyagrottama" Kept at the IOM, RAS
}

Abstract: This paper introduces a small Tibetan book from Dunhuang kept at the IOM, RAS. It is a copy of 'Phags pa ting nge 'dzin mchog dam pa, one of the Buddhist sūtras that emphasize the importance of the practice of samādhi. Some paleographical features of the manuscript as well as its contents are characterized. The manuscript presents a version of 'Phags pa ting nge 'dzin mchog dam pa that is different from those of later editions of the Tibetan Buddhist Canon. Its comparison with fragments of two other Dunhuang copies of the same text found in Paris supports my assumption that an old version of the sūtra did exist.

Key words: Tibetan manuscripts, Dunhuang, Buddhist sūtras, Ārya-samādhyagrottama, paleography, textology.

The collection of Tibetan Dunhuang manuscripts kept at the IOM, RAS consists mostly of the copies of two popular texts, Aparimitāyurjūāna-sütra (204) and Prajñāpāramitā-hrdaya-sütra (10), all of them being rather standard scrolls. In addition to them there are three small-sized pothi books and two concertina books that provide some important textological data on the initial stage of the spread of canonical Buddhist literature in Tibetan. The three pothi books and two scrolls with Aparimitāyurjñāna-sūtra were a part of the first package with Dunhuang materials acquired by the St. Petersburg Academy of Sciences. In 1911, the package was sent by Nikolai Krotkov (1869-1919), the Russian consul in Urumqi, ${ }^{1}$ and it was passed to the Asiatic Museum (now the IOM, RAS). ${ }^{2}$ The two concertina books were delivered to it in 1917 , they had also been acquired by N. Krotkov. ${ }^{3}$

(C) Alexander Valerievich Zorin, Institute of Oriental Manuscripts, Russian Academy of Sciences

${ }^{1}$ On Krotkov see PANG 2006, BuKHARIN 2016.

${ }^{2}$ On the history of the collection see ZoRIN 2012.

${ }^{3}$ I identified these two books while processing the IOM, RAS Tibetan collection and passed them to the collection of Tibetan Dunhuang manuscripts, in 2015. 


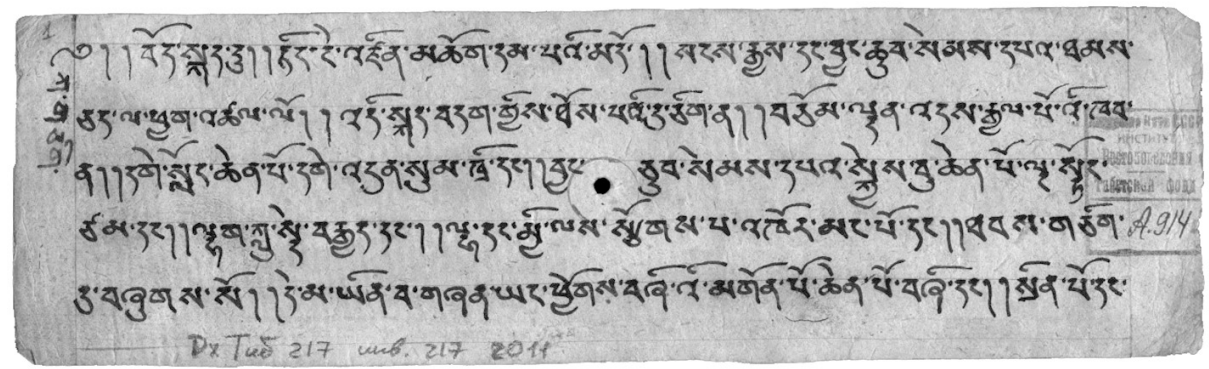

Pl. 1: The first page of Дх. Тиб. 217

This paper presents a preliminary analysis of one of the books, Дх. Тиб. 217, that contains a single text, namely 'Phags pa ting nge 'dzin mchog dam pa (Skt. Arya-samādhyagrottama). The size of the book is $28.2 / 28.4 \times 8.5 / 8.5 \mathrm{~cm}$. It consists of 28 folios of rather thick brownish paper, presumably produced in Dunhuang. There is no title page, the text starts right on the recto side of $\mathrm{f}$. 1 with the standard initial part that contains the titles in Sanskrit and Tibetan (P1. 1). Both recto and verso sides of each folio have five horizontal lines (f. $27 \mathrm{v}$. - six, f. $28 \mathrm{v}$. - two), written along thin bars so that the so-called heads $(d b u)$ of the Tibetan letters are evenly placed under them. On ff. 1-18, the fifth of the bars is the lower border of the text space, the other folios have bars put less regularly. Vertical bars divide right and left margins of the folios. The left margins of the recto sides have the Tibetan letter $K a$ and page numbers from 1 to 28 written in the upper part of the margin. Moreover, each folio has a hole in the center marked with a circle around it. The text and the bars are in black.

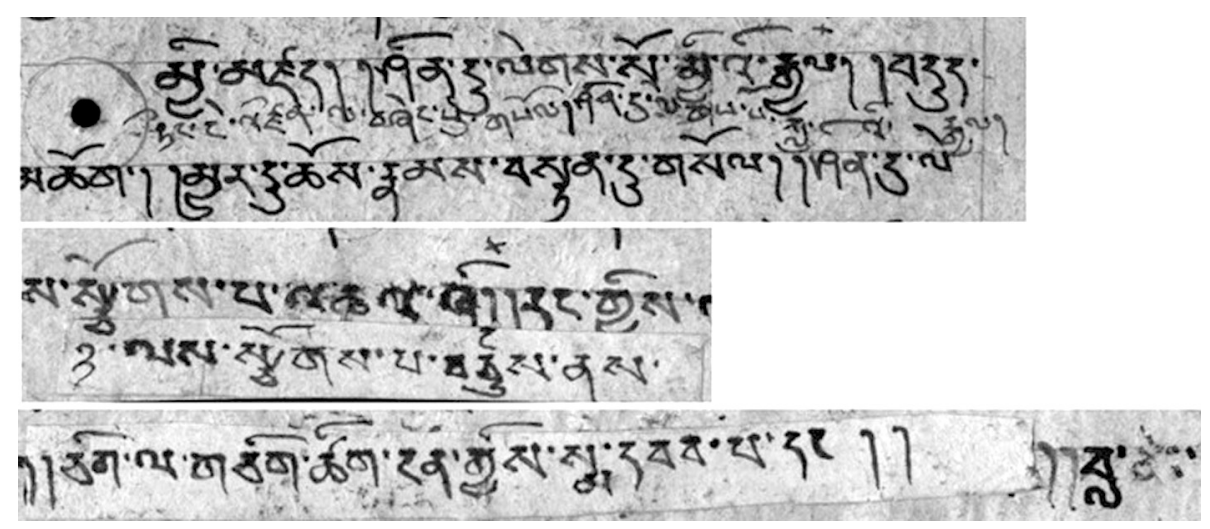

Pl. 2: Some examples of corrections of the text made by the scribe:

1) f. 2 r.; 2) f. 22 r.; 3) f. 22 v 


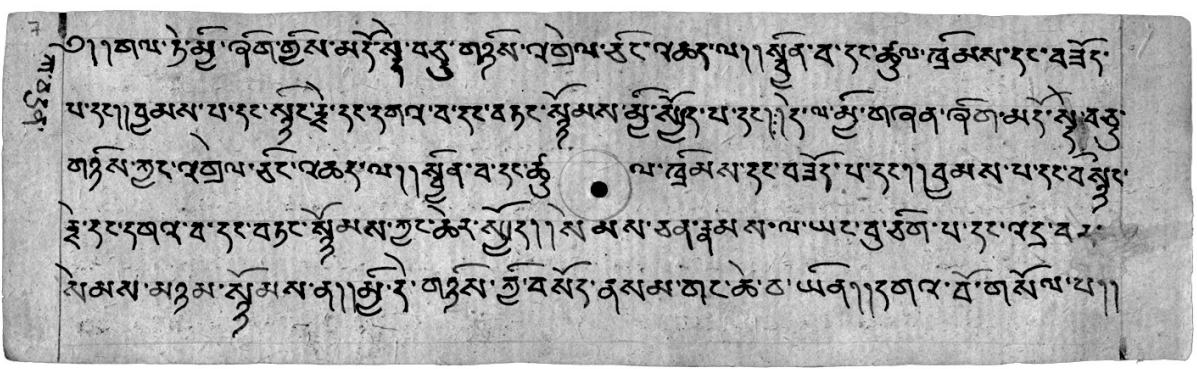

P1. 3: F. 7 r.

Note: 1) the my- pattern in myi zhig, myi spyod, myi gzhan etc.; 2) the inverted gi gu sign in bsnyIng; 3) the special ligature for sp- in spyod; 4) the syllable 'tshul' divided with the encircled hole into two parts; 5) the |:| sign which is used to mark the end of the Buddha's and Nanda's replicas in this manuscript (ff. 2-9) but put in this particular place mistakenly

The manuscript seems to have been produced by one scribe, of moderate calligraphic skills, although the size of the letters may differ. The text was revised by the same person:

- a number of syllables were diligently rubbed away and replaced with correct ones so that the former inscriptions are usually illegible;

- some fragments are added below the text, such places being normally marked with plus signs or small cross signs;

- f. 22 has a paper application with a revised fragment on each side with 6 syllables on the recto side, and 10 syllables on the verso side (Pl. 2).

The following features relating to orthography of the manuscript, indicating the use of old orthography and, in certain cases, some peculiarities of the scribe, can be listed (Pl. 3):

- the $m y$ - pattern for words that, according to new orthography, start with $m i$ - and $m e$ - is normally used;

- the inverted gi gu sign is attested from time to time;

- particles ' $i$ and ' $o$ (with the letter 'a chung) are usually separated from the preceding syllables with the tsheg sign (e.g. bcu 'i, bya 'o, etc.);

- a special ligature for the combination $s p$ - (as in spyod or spong, etc.) is used, it is similar to the one used in $d b u$ med script (this feature is shared with some later mss, e.g. Ablaikit Kagyur); 
- some words have peculiar orthography, namely byang cub for byang chub, rin cen for rin chen (but rin po che), bsam (b)rtan for bsam gtan (the latter form is used once), las stsogs for la sogs, the tsom for the tshom, khyed bar for khyad par, bstan chos/bstan cos for bstan bcos, ngan tshong for ngan song;

- some syllables are divided into two parts due to a lack of space because of either the hole in the center of each folio or the end of the line (e.g. bsla - bs, tshu - l khrims, myi $g$ - zhan, etc.) (again, this feature is attested in later mss such as Ablaikit Kagyur or some Kalmykian mss from the late 18th to early 19th cc. preserved in the IOM, RAS);

- extra 'a chung letters are rarely added to syllables, e.g. brgya', seng 'ge but they may be simple errors of the scribe since in other cases the same syllables are written without them, some phonetic mistakes are found in the words skug gzugs, rgyal mtsho and sna mtshogs;

- unlike some other Dunhuang mss, Дх. Тиб. 217 has no tsheg signs before the shad signs, even after the words with the final letter $n g$;

- ff. 2-9 mark the ends of the phrases of the Buddha and his disciples with vertical dotted lines written in between the double shad signs, that can be rendered as $|\vdots|$ | (the actual number of dots is either four or five).

Before we turn to textological comparison of the manuscript with later versions of the Tibetan text of the sūtra as preserved in various editions of Kagyur let us consider its contents and place amidst other canonical texts.

The synopsis of The Holy [Sütra] of the Most Supreme Samādhi can be presented as follows:

The Buddha resides in Rājagrha along with his retinue whose description is provided. The Buddha enters the samādhi of light ('od zer gyi ting nge 'dzin) and utters no words for some time so that his retinue starts being worried. Mañjuśrī recites a prayer asking the Buddha to leave the samādhi and explain the meaning of the single vehicle. The Buddha leaves the samādhi and asks his disciples not to worry and put him any questions.

One of them, Nanda (Dga' bo), starts a long dialogue with the Teacher asking about the reason, why he, Nanda, cannot attain the Enlightenment even though he heard so many teachings. The Buddha explains that learning a lot is not effective, if one does not practice the samādhi, which is like "the lion amidst the beasts" or "Sumeru amidst the mountains". By means of a long series of comparisons he shows to Nanda how much precious and meritorious this practicing is, being the only way to enter and realize the full meaning of his teachings. 
The Buddha tells a story about one of his previous lives in which Mañjuśrī and he, both proud with their erudition, argued over the nature of the world - if it is perishable or eternal. Clinging to wrong views brought them to the hell in the next rebirth. After escaping terrible tortures they met the Buddha Kaśyapa, who explained to them that the world was neither perishable nor eternal. The meaning of emptiness, etc. was realized by the Buddha after he practiced the samādhi for a week. ${ }^{4} \mathrm{He}$ describes how great is the power of the samādhi that can "pacify" the hardest evil deeds. Using it, one can see the entire universe in plain sight, make inconceivable miracles, etc. The Buddha refers to great miracles performed by Maudgalyāyana and states that they cannot be repeated by those who just "heard a lot".

Five hundred erudite monks, who have stayed at the Bamboo Grove, hear the Buddha's words about Maudgalyāyana's abilities and join the conversation. They exclaim that they rather abandon learning and start practicing the samādhi, but the Buddha claims that doing so would be like crossing the sea without a ship, etc. He explains four stages of dhyāna and various technical aspects of their practicing (e.g. the way one should meditate on one's body). The monks start practicing according to his instructions and in seven days become the Arhats and make many miracles following the Buddha's invocation.

Afterwards, Nanda asks the Buddha for how long the sentient beings practicing the Dharma can obtain the virtuous results after he passes away. A detailed prophecy by the Buddha follows. According to it, after a long period of gradual degradation, ${ }^{5}$ the time will come, when the Buddha's disciples cannot obtain the four virtuous results, his temples and caityas get all empty, etc. Nanda gets much distressed, but the Buddha calls him to stop crying and do his best to spread Buddhist sūtras in the world. Nanda takes an oath to do it. Indra, deities and human beings promise Nanda that they will go to any place to listen to those who would recite the sūtras, even a single śloka or a single word of them. A lot of the Buddha's disciples, who have heard this sūtra, achieve various virtuous goals.

Thus, the main idea of the sūtra is that, although learning various aspects of the Buddhist teaching is important, it is only through practicing the

${ }^{4}$ The English translation of this fragment of the sūtra is provided in SHANTARAKSHITA 2011, 249.

${ }^{5}$ Describing the faults of the Buddha's followers in the times coming, the Tibetan text of the prophecy uses the word bon chos that reminds us about the practice of translators of Chinese apocryphal sūtras (cf. vAN SCHAIK 2013, 252-253). 
samādhi that the virtuous goals can be achieved. In this sense, the samādhi is called supreme. In the later sets of the Tibetan Buddhist canon this text was placed amidst other sūtras dealing with the theme of the samādhi practicing (vols. Thu and Du in Peking edition, Da and $\mathrm{Na}$ in Derge edition).

This particular sūtra was produced more than once in Dunhuang. There were at least two more manuscript copies - I could identify two folios from them. They are preserved at the National Library of France, Paris, as Pelliot tibétain 720 and Pelliot tibétain 900 (one of the two folios, the other belongs to a different text). ${ }^{6}$ A question may arise - why was this sūtra repeatedly reproduced as a separate text? My speculative assumption is that the answer should be found in the eloquent Buddha's prophecy and the urgent call to spread the sūtra in the world.

The text of Дх. Тиб. 217 has a lot of different readings in comparison with the later canonical editions which are not purely orthographical variations but significant ones, with different words or different order of words used. There are even three long passages that our manuscript lacks and, on the contrary, two passages that the later editions lack. Although the lack of some fragments of the text in our manuscript could be explained with lapses of the scribe, the lack of its own fragments in later editions hints at the existence of a principally different older version of the sūtra.

The comparison of Дх. Тиб. 217 with fragments kept in Paris is demonstrated below. Both Paris folios (Pel.) are in many cases closer to the later Kagyur versions $(\mathrm{K})$ which are more or less the same in spite of few insignificant variations that can be omitted here. There are also some important similarities between Pel. and Дх. Тиб. 217 that contradict K (marked bold). The following transliteration is based on Дх. Тиб. 217 (No. 720 : ff. 8r.4-1v.1; No. 900: 15 r.3-16v.1) but it is arranged according to the Paris folios; the readings of $\mathrm{K}$ are borrowed from the modern comprehensive Beijing ed. (cf. KAGYUR 2006-2009: 489-490; 494-495, resp.).

\section{0r.}

snyoms kyang spyod de| |tshul khrims chal [Pel./K 'chal] pa dang | tshul khrims bsrungs la [Pel. srung ba la; $\mathrm{K}$ srung ba dang] la yang [Pel./K -la

${ }^{6}$ This identification was made with the use of the search tool of the IDP web-site that presents the transliteration of the initial lines of the fragments; some other fragments may be found over time. The two identified folios are too different in regard to their size and some textual features ( 6 and 5 lines per page resp., No. 720 has a decorative hole in the center) to have belonged to one manuscript. But the scribe of both ff. seems to be the same. 
yang $\left.^{7}\right]$ sems gnyis su myed cing| |nam ka [K mkha'] ltar mnyam ste [Pel./K mnyam ba/pa dang] | |sems can gyi skyon thams cad myi mthong zhing| | $[\mathrm{K}-||]<$ sems can rnams la $>^{8}$ bu cig [Pel./K gcig] pa dang 'dra bar snyoms ste [Pel. de; $\mathrm{K}$ te] | |dgra sdang ba la yang nam ka [K mkha'] ltar mnyam [Pel. bnyam] ba dang| |de la myi zhig phyogs su brgyas [Pel./K rgyas] pa'i mdo sde bcu gnyis la skur pa myi 'debs na| | [K -| |] myi de gnyis <kyi bsod nams gang che ba> yin| |dga' bo gsol pa| |phyogs su rgyas pa'i mdo sde bcu gnyis la skur pa ma btab na| |myi de 'i bsod nams ni tshad myed grangs myed de [ $\mathrm{K}$ tshad ma mchis grangs ma mchis te] | bsam gyis mi khyabs [Pel. 'khyab; K khyab] bo [K pa lags so] | | <bcom ldan 'das kyis [K dga' bo la] bka>' stsal pa| |gzhan yang myi zhig gyis [Pel. gis; K gi] gong du smos pa'i bsod nams thams cad kyang [Pel. |] stong gsum gyi stong chen po ' $\mathrm{i}$ 'jig rten gyi khams gang bar byed nus la $<\mid$ mdo sde bcu gnyis dang $\mid$ bs $>\tan$ chos ' $u$ da [Pel./K ta] bco lnga snyed kyang kha ton [Pel. thon] dang | [K -| |] 'grel [K 'brel] zhing [Pel./K cing] 'chad nus ste [Pel./K te] | |tshul khrims dang bzod pa dang| |byams pa [K byams pa la sogs pa] yang spyod| |sbyin pa yang byed de| |mang du thos pa'i mchog tu yang gyur la| |[K -||$]$ chos thams $<$ cad kyang [K -kyang] stong zhing zhi ba'i don> yang ston to [Pel./K te] | |nyan pa'i rnams [K -rnams] mngon bar shes pa lnga [Pel. la] thob par byed de| |de ltar phan ba dang [Pel. |] bde ba'i don byas kyang [Pel. |] des [Pel./K des ni] myi zhig nyin cig [Pel./K gcig] gam| |mtshan gcig gam [Pel./K gam] ting nge 'dzin du zhugs

720v.

$<$ pa tsam myi phod do| :|de ci >'i phyir zhe na|| mang du thos pa'i gang zag ni| |ri 'am rgyal [Pel./K rgya] mtsho ltar nga rgyal kyi [Pel./K gyi] sems che 'o| |de ltar nga rgyal che ba ni [Pel. |] ngan tshong [Pel./K song] gsum [Pel./K - gsum] du bskal pa grangs myed pa'i [K kyi] bar du sdug sngal [Pel./K bsngal] myong bar <'gyur ro| |dmyal ba de las $>$ [Pel. |] thar na yang| |'dab chags kyi [Pel. gyi] bar [K byar] skye bar 'gyur na| | [K -| |] mang du thos pa la ni [Pel./K -ni] phan ba ci yod| |gang la bsam gtan gyi ting nge 'dzin yod pas [Pel/K pa] ni| | [Pel./K - | |] skye shi 'i [Pel. shir] 'khor ba'i sdig pa [Pel. -sdig pa; K -pa] kha na ma tho ba'i las lci ba <byang bar nus so| | mang du th>os pa ni rtswa dang 'dra [K'dra'o] | |bsam gtan gyi [Pel./K -bsam gtan gyi] ting nge 'dzin ni mye dang 'dra 'o [Pel. -'o] | |mang du thos pa ni lcags dang 'dra [K'dra'o] | |bsam rtan [Pel./K gtan] gyi ting nge 'dzin ni gser dang 'dra 'o| |mang du thos pa ni rtswa gtubs [Pel. gdugs; K rtsi

\footnotetext{
${ }^{7}$ Absent parts are marked with the minus (-) sign.

${ }^{8}$ The left edge of this Paris folio is damaged.
} 
bdug] pa dang 'dra [K 'dra'o] ||$<$ bsam rtan gyi ting nge 'dzin $>$ ni rtswa 'i snying [Pel./K rtsi'i sdong] po dang 'dra 'o| |mang du thos pa ni gtsang [Pel. rtsang] po dang 'dra [K'dra'o] | bsam rtan [Pel./K gtan] gyi ting nge 'dzin ni rgyam [Pel./K rgya] mtsho dang 'dra ste| |nga [Pel./K ngas] bsam rtan [Pel./K gtan] gyi ting nge 'dzin gyi [Pel. ting nge 'dzin gyi ting nge 'dzin] $<$ bsod nams dang yon tan $>$ bshad na| | [Pel./K -| |] zad pa'i mtha' myed de| | $[\mathrm{K}-||$ |] bskal par yang bshad te [Pel./K -bshad de] myi rdzogs so| |bcom ldan 'das kyis [Pel./K dga' bo la] bka' stsal pa| |nga mngon [K sum] du dran ba sngon 'das pa'i dus cig [Pel./K -cig] na| | [K -| |] mang du thos <pa'i skye bor gyur pa'i tshe na [K -na] | |'>jam dpal dang [K dang nga gnyis] yod myed gnyis kyi bden pa la brtsod [Pel. yod med gyi bden ba gnyis las rtsod; $\mathrm{K}$ yod med gnyis la rtsod] par gyur te | |'jam dpal ni yod do [K -do] zhes [K ces] smra| |ngas [Pel. nga] ni myed do zhes smras ste [K te] | yod myed gnyis kyi [Pel. gyi] bden ba las [Pel./K la] bstsod [Pel./K rtsod] par gyur te| |gcig du

\section{0r.}

tsam zhig tham $+\circ \mathrm{s}$ cad mang du thos pa slob [K rlom] pa las| |bcom ldan 'das kyis dga' bo la| | [K - |] me'u 'gal [K maud gal] gyi bu 'i rdzu 'phrul dang |ting nge 'dzin mchog go zhes gsungs pa thos nas| | [K -| |] sangs rgyas gang na bar der lhags te [Pel. ste; K nas] | |bcom ldan 'das kyi zhabs la mgo bos phyag 'tshal nas | [K - | ] sangs rgyas la 'di skad ces gsol to| |bcom ldan 'das bdag cag mang du thos pa bslabs te| |mdo sde bcu gnyis kyang [Pel. |] khong du chud pas $\mid$ | [K -| |] rgyal khams chen po bcu drug snyed kyang| | $[\mathrm{K}-||]$ bdag cag la sangs rgyas dang 'dra bar gus shing bkur sti bgyid [Pel. bgyis; K bgyi] na| |ci 'i slad du bcom ldan 'das kyis mang du thos pa [Pel. pa'; K pa ni] nam [Pel. rnams] yang [Pel. yang dag pa] bla na myed pa'i byang cub $[$ Pel./K chub] thob par myi 'gyur ro $[\mathrm{K}||]$ zhes

900v.

gsungs [Pel. gsung] shes [Pel./K zhes] gsol pa dang | [K bcom ldan 'das la] dge slong lnga rgya po mthun bar ||$[$ Pel./K - | |] dus gcig du [Pel. |] bdag cag ni mang du thos pa spang zhing $\mid[\mathrm{K}-||]$ bsam [Pel./K gtan] gyi ting nge 'dzin slobs [Pel. slob; K la slob] bo zhes gsol tol |bcom ldan 'das kyi [Pel. kyis|; K kyis] dge slong rnam [Pel./K rnams] la bka' stsal pa| |dge slong khyed mang du thos pa spangs [Pel. spang] ste [K te] | |bsam rtan [Pel./K gtan] gyi ting nge 'dzin la 'jug go zhes ma smra cig [Pel./K shig]| |ngas ltas [Pel./K bltas] na khyod [Pel./K khyed] kyi shes pa [K shes rab] ni [Pel. |] sbrang ○ bu 'i 'dab mas [Pel. |] nyis [Pel. gnyi; K nyi] zla sgribs [Pel. bsgrib; $\mathrm{K}$ sgrib] par 'dod pa dang| |dmus long gyis [Pel./K gis] ri rabs [K rab] lhun po la 'dzag [Pel./K 'dzeg par] 'dod pa dang| |gru gzings myed par rgya 
mtsho la rab [Pel./K rgal] 'dod pa dang| |bya 'dab ma chags [K chag] pa [Pel. pas] nam ka [K mkha'] la phur [Pel./K 'phur] 'dod pa bzhIn du| | [K -du| |] khyed kyang de dang 'dra ste| | [Pel/K. 'dra'o] zhes [Pel. |] bka' stsal pa dang| |dge slong de [K -de] rnam [K rnams] shi ba tsam du 'jig [K 'jigs] shing bskrags [Pel. skrags; K skrag] pa'i

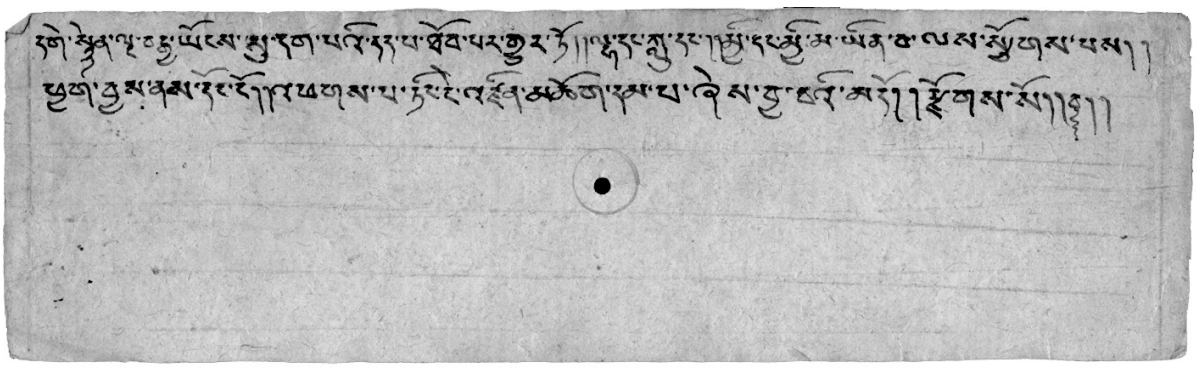

Pl. 4: F. 28 v. - the colophon

It would be surely desirable to compare the Dunhuang manuscripts of the sūtra with the oldest manuscripts of the Tibetan Buddhist canon. The Wien University Project "Resources for Kanjur\&Tanjur Studies" (RKTS) provides us with the colophons of the sūtra as found in all known canonical sets, including Old Mustang Kanjur, Phugbrag Kanjur, etc. None of them is identical with that of Дх. Тиб. 217 that runs as follows - 'phags pa ting nge 'dzin mchog dam pa zhes bya ba'i mdo| |rdzogs so $\mid$, the words zhes bya ba' $i$ mdo being its unique feature (Pl. 4).

Thus, it is possible that the pothi manuscript Дх. Тиб. 217 has preserved for us an ancient version of the Tibetan translation of Arya-samädhyagrottama. The sūtra was reproduced more than once in Dunhuang, at least three copies were made - one full copy is found in St. Petersburg and single folios from two other copies were identified in the Paris collection; its relative popularity may be connected with the Buddha's prophecy and his urgent call to spread the sūtra. The further study of Tibetan texts from Dunhuang preserved in various collections may help identify more fragments of this sūtra to give us new information on the circumstances of the transmission and development of this text in Tibetan. 


\section{References}

BUKHARIN M.D. 2016: "My oba rabotaem dlya Rossii, dlya nauki...”. Perepiska S.F. Ol'denburga i N.N. Krotkova iz arkhivnykh sobranii RAN" ["We both work for Russia, for science...": Correspondence of S.F. Ol'denburg and N.N. Krotkov from the archival Collections of the Russian Academy of Sciences]. Introduction and edition by M. D. Bukharin. Scripta antiqua. Voprosy drevnei istorii, filologii, iskussstva i material'noi kul'tury [Scripta antiqua. Issues of ancient history, philology, arts and material culture], V, 395-457.

IDP: Inventaire des manuscrits tibétains de Touen-houang conservés à la Bibliothèque Nationale (Fonds Pelliot tibétain) at the web site of the International Dunhuang Project: Nos 1-849, I — http://idp.bl.uk/database/oo_cat.a4d?shortref=PelliotTibetain_I; Nos 8501282, II — http://idp.bl.uk/database/oo_cat.a4d?shortref=PelliotTibetain_II [10.02.2018]

KAGYUR 2006-2009: 'Phags pa ting nge 'dzin mchog dam pa. Bka' 'gyur dpe bsdur ma. Vol. 56. Pe cin: krung go'i bod rig pa'i dpe skrun khang.

PANG T.A. 2006: "N. N. Krotkov's Questionnaire to Balishan Concerning Sibe-Solon Shamanism". In: Tumen jalafun jecen akū. Manchu Studies in Honour of Giovanni Stary. Ed. by A. Pozzi, J. A. Janhunen, and M. Weiers. Wiesbaden, Harrassowitz Verlag, p. 201210.

RKTS: entry on 'Phags pa ting nge 'dzin gyi mchog dam pa at the web-site of the project "Resources for Kanjur\&Tanjur Studies" — https://www.istb.univie.ac.at/kanjur/rktsneu/ verif/verif2.php?id=137 [10.02.2018]

ShantaraKshita 2011: The Adornment of the Middle Way. Shantarakshita's Madhyamakalankara with commentary by Jamgön Mipham. Translated by the Padmakara Translation Group. Boston and London: Shambhala. [E-book.]

VAN SCHAIK, Sam 2013: "The Naming of Tibetan Religion: Bon and Chos in the Tibetan Imperial Period". Journal of the International Association for Bon Research 1, 227-257.

ZoRIN A.V. 2012: "The Collection of Dunhuang Tibetan Texts Kept at the IOM RAS". Dunhuang Studies: Prospects and Problems for the Coming Second Century of Research. Ed. by I. Popova and Liu Yi. St. Petersburg: Slavia Publishers, 365-367. 